\section{Trace metal distribution in groundwater and surface soils of Fazilka district, SW Punjab, India.}

SHEFALI CHANDER AND SUSANTA PAIKARAY PANJAB UNIVERSITY

Presenting Author: shefali23@pu.ac.in

Regional hydraulic gradient towards southwest (SW) in Punjab, India turned the Fazilka district into a wet desert with concerns of poor soil and water quality. Selected surface soils and groundwater from bore wells and tube wells up to $450 \mathrm{ft}$ depth were examined for trace metal distribution. Manganese content in the studied soil was the highest and $U$ the least in the order $\mathrm{Mn}>\mathrm{Zn}>\mathrm{Cr}>>\mathrm{Ni}>\mathrm{Cu}>\mathrm{As}>\mathrm{Co}>\mathrm{Se}>\mathrm{Th}>\mathrm{U} \quad($ Table 1). Contrarily, $\mathrm{U}$ content in groundwater were greater than other trace metals at all depths in the order $\mathrm{U}>\mathrm{Zn}>\mathrm{Mn}>\mathrm{Cr}>\mathrm{Cu}>\mathrm{Se}>\mathrm{As}>\mathrm{Ni}>\mathrm{Co}>\mathrm{Th} . \quad$ A circum-neutral to alkaline nature $\left(\mathrm{pH}\right.$ 7.06-8.44) with $\mathrm{Na}^{+}-\mathrm{HCO}_{3}^{-}$water type characterizes the groundwater. Exceptionally high dissolved solids (171-3180 mg/L) and salinity (200-2500 mg/L) were measured. The intermediate depth (i.e., 100-250 ft) is enriched in trace metals except shallow depth enrichment of $\mathrm{Zn}$ and $\mathrm{Ni}$, while groundwater $>350 \mathrm{ft}$ contains very less trace metals. Uranium contents are beyond WHO permissible limit of $30 \mu \mathrm{g} / \mathrm{L}$ in $\sim 90 \%$ of studied groundwater, whereas western part of the district nearer to Sutlej river contains $U<30 \mu \mathrm{g} / \mathrm{L}$. A contrasting behavior of trace metals and $U$, i.e., high dissolved $U$, but poor soil contents and the opposite for other trace metals, is indicative of alkalinity favored $U$ mobilization from aquifer sediments, whereas the prevailed grochemical condition might not be favorable for other trace metal release, rather remained intact with soil constituents like Fe-Al oxides and organic matters. The increased trace metal contents at intermediate depth might have caused by surface infiltration processes.

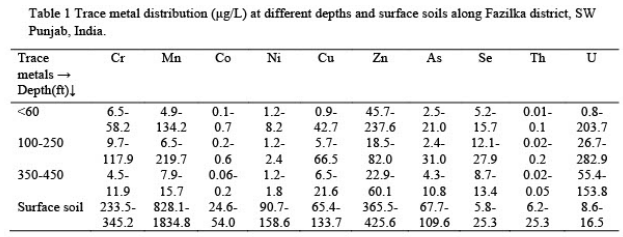

